\title{
REFORMASI BIROKRASI BIDANG PERIZINAN BERDASARKAN UNDANG-UNDANG NOMOR 25 TAHUN 2009 TENTANG PELAYANAN PUBLIK (STUDI DI KABUPATEN BOGOR)
}

\author{
Suwari Akhmaddhian \\ Fakultas Hukum Universitas Kuningan \\ E-mail : suwariakhmaddhian@gmail.com
}

\begin{abstract}
Abstrak Keterbukaan informasi merupakan bagian penting dari reformasi birokrasi yang pada hakikatnya merupakan upaya untuk melakukan pembaharuan dan perubahan mendasar terhadap sistem penyelenggaraan pemerintahaan sehingga tercapai tujuan reformasi birokrasi yaitu untuk mempercepat tercapainya tata kelola pemerintahan yang baik dan upaya memperbaiki dukungan terhadap pemerintah daerah dalam meningkatakan kinerjanya. Reformasi birokrasi berjalan terdiri dari reformasi kelembagaan, sumber daya manusia dan reformasi manajemen dukungan teknologi informasi. Reformasi birokrasi perizinan penanaman modal di kabupaten Bogor sudah dan sedang berjalan dalam upaya meningkatkan pelayanan terhadap masyarakat sehingga tata kelola perizinann yang baik di rasakan oleh masyarakat luas. Reformasi manajemen dukungan teknologi informasi dalam proses perizinan yaitu meningkatkan keterbukaan informasi melalui keterbukaan manajemen dalam mempublikasikan hal-hal yang berkaitan dengan proses perizinan mulai dari syarat, proses tahapan dan biaya dengan dukungan teknologi informasi.
\end{abstract}

Kata kunci : Birokrasi , Informasi, Keterbukaan, Perizinan, Reformasi.

\section{BUREAUCRATIC REFORM OF LICENSING IS BASED ON LAW NO. 25 OF 2009 ON PUBLIC SERVICE (STUDIES IN BOGOR REGENCY)}

Abstract Disclosure of information is an important part of the reform of the bureaucracy which in essence is an attempt to reform and fundamental changes to the systems of governance in order to reach the goal of bureaucratic reform is to accelerate the achievement of good governance and efforts to improve support to local governments by increasing its performance . Reform of the bureaucracy runs consisting of institutional reform, human resources and information technology support management reform. Investment licensing bureaucracy reform in Bogor district already up and running in an effort to improve service to the public so that good governance licensing felt by the wider community. Information technology support management reform in the licensing process is to increase transparency through disclosure of information management in publishing matters relating to the licensing process ranging from requirements, process stages and the cost of information technology support .

Keywords: Bureaucracy, Disclosure, Information, Licensing, Reform.

\section{PENDAHULUAN}

Keterbukaan informasi merupakan suatu keharusan dalam membangun kepercayaan masyarakat yang se-makin menurun terhadap pemerintahan dan khususnya bidang perizinan. Pembangunan ekonomi menjadi salah satu jalan dalam mensejahterakan masyarakat. Dalam pembangunan ekonomi di perlukan birokrasi yang ramah terhadap penanaman modal. Dalam pem-bangunan ekonomi terkait erat dengan bergeraknya sektor ekonomi yang menciptakan lapangan kerja bagi masyarakat sehingga tujuan Negara dalam memakmurkan rakyatnya tercapai.

Publik harus terus menerus memberikan kritik membangun, menyampaikan aspirasinya, dan berpartisipasi. Dengan adanya reformasi birokrasi diharapkan menjadi tatanan dalam kehidupan masyarakat sehingga dengan adanya tatanan dalam kehidupan masyarakat menjadi serba teratur sehingga tercipta nilai dasar dalam masyarakat yaitu tentang keadilan, kepastian hukum dan kemanfaatan sosial (Asri M Saleh, 2004, 232). Pelayanan publik yang berkualitas menjadi salah satu tolok ukur untuk melihat apakah disuatu organisasi pemerintah (sektor publik) telah terjadi reformasi birokrasi. Masifnya kesan miring yang muncul atas pelayanan publik yang dilakukan oleh sektor publik, tidak terlepas dari kenyataan bahwa rendahnya kualitas pelayanan publik yang diberi- kan kepada masyarakat sebagai konsumen. Rendahnya pelayanan publik dimaksud, antara lain ditandai dengan : pertama, tidak transparannya biaya dalam pengurusan perizinan. Kedua, berbelit-belitnya pelayanan bahkan tidak jarang membuat masyarakat menjadi frustasi. Ketiga, waktu pelayanan yang tidak jelas, sehingga masyarakat tidak dapat memprediksi kapan selesainya.

Menurut Davidow (dalam Lovelock, 1988) pelayanan adalah : "Service is those thing which when added to a product increase its utility or value to the customer". Pelayanan sendiri adalah hal-hal yang jika diterapkan terhadap suatu produk akan meningkatkain daya atau nilai terhadap pelanggan. Lebih jauh Lovelock (1988) berpendapat bahwa pelayanan yang baik membutuhkan instruktur pelayanan yang sangat baik pula. Hal ini bahwa yang paling penting adalah membuat setiap orang dalam organisasi berkualitas. Kualitas pelayanan sendiri menurut Crosby, Lehtimen, dan Wyckoff (dalam Lovelock, 1988) merupakan penyesuaian terhadap perincian-perincian (conformance of specification), dimana kualitas ini dipandang sebagai derajat keunggulan yang ingin dicapai, dilakukannya kontrol terus menerus dalam mencapai keunggulan tersebut dalam rangka memenuhi kebutuhan pengguna jasa (Riyadi Soeprapto, 2005, 135). 
Maklumat pelayanan adalah pernyataan tertulis yang berisi keseluruhan rincian kewajiban dan janji yang terdapat dalam standar pelayanan. Sistem informasi pelayanan publik yang selanjutnya disebut Sistem Informasi adalah rangkaian kegiatan yang meliputi penyimpanan dan pengelolaan informasi serta mekanisme penyampaian informasi dari penyelenggara kepada masyarakat dan sebaliknya dalam bentuk lisan, tulisan Latin, tulisan dalam huruf Braile, bahasa gambar, dan/atau bahasa lokal, serta disajikan secara manual ataupun elektronik. Mediasi adalah penyelesaian sengketa pelayanan publik antarpara pihak melalui bantuan, baik oleh ombudsman sendiri maupun melalui mediator yang dibentuk oleh ombudsman. Ajudikasi adalah proses penyelesaian sengketa pelayanan publik antar para pihak yang diputus oleh ombudsman. Ombudsman adalah lembaga negara yang mempunyai kewenangan mengawasi penyelenggaraan pelayanan publik, baik yang diselenggarakan oleh penyelenggara negara dan pemerintahan termasuk yang diselenggarakan oleh badan usaha milik negara, badan usaha milik daerah, dan badan hukum milik negara serta badan swasta, maupun perseorangan yang diberi tugas menyelenggarakan pelayanan publik tertentu yang sebagian atau seluruh dananya bersumber dari anggaran pendapatan dan belanja Negara dan/atau anggaran pendapatan dan belanja daerah. Masyarakat memiliki hak untuk melakukan pengawasan karena penyelenggaraan pemerintahan dan penyelenggaraan Negara adalah mandate yang di berikan rakyat melalui pemilihan umum sehingga rakyat dapat memperoleh pelayanan publik yang baik (Asmara Budi Dyah Dharma Sutji, 2008, 72).

Ombudsman adalah badan atau petugas independen yang bertugas menampung keluhan-keluhan masyarakat tentang perilaku pegawai negeri yang tidak benar seperti penyalahgunaan wewenang, kelambatan penyelesaian tugas, dan lainnya. Bidang kerja ombudsman juga berhubungan dengan masalah-masalah perlindungan konsumen, hak sipil, perpajakan, lingkungan, lembaga pemasyarakatan, dan sebagainya. Lembaga ini kemudian meneliti, melaporkan, mengusulkan pemecahan masalahnya kepada pemerintah. Secara yuridis lembaga ombudsman tidak, mempunyai wewenang kekuasaan, namun dengan keritikan, teguran dan publisitas, maka diharapkan dapat mempengaruhi pemerintah dalam menjalankan tugas-tugas pemerintahan secara baik (Asri M Saleh, 2004, 233).

Undang-undang No. 25 Tahun 2009 tentang Pelayanan Publik dimaksudkan untuk memberikan kepastian hukum dalam hubungan antara masyarakat dan Penyelenggara dalam pelayanan publik. Yang mempunyai tujuan yaitu: terwujudnya batasan dan hubungan yang jelas tentang hak, tanggung jawab, kewajiban, dan kewenangan seluruh pihak yang terkait dengan penyelenggaran pelayanan publik; terwujudnya sistem penyelenggaraan pelayanan publik yang layak sesuai dengan asas-asas umum pemerintahan dan korporasi yang baik; Terpenuhinya penyelenggaraan pelayanan public sesuai dengan peraturan perundangundangan; dan Terwujudnya perlindungan dan kepastian hukum bagi masyarakat dalam penyelenggaraan pelayanan publik. Dalam Undang-undang No. 25 Tahun 2009 tentang Pelayanan Publik Pasal 4 menyatakan bahwa Penyelenggaraan pelayanan publik berasaskan yaitu: kepentingan umum; kepastian hukum; kesamaan hak; keseimbangan hak dan kewajiban; keprofesionalan; partisipatif;. persamaan perlakuan/tidak diskriminatif;. keterbukaan;. akuntabilitas;. fasilitas dan perlakuan khusus bagi kelompok rentan; ketepatan waktu; dan. kecepatan, kemudahan, dan keterjangkauan.

Dalam artikel ini mempunyai rumusan masalah yang mencoba menggambarkan mengenai pokok permasalahan yang ada. Adapun yang menjadi pokok permasalahan yang akan menjadi fokus perhatian utama yang akan dibahas dalam penelitian ini dapat di uraikan dalam pertanyaan diantaranya sebagai berikut:

a) Bagaimana reformasi birokrasi bidang Perizinan di Kabupaten Bogor.?

b) Bagaimana pengaruh reformasi birokrasi terhadap Keterbukaan Informasi dii Badan Perizinan Terpadu Kabupaten Bogor.?

\section{METODE}

Metode penelitian yang digunakan oleh penyusun dalam pembahasan penelitian ini adalah metode evaluatif analisis, yaitu suatu metode mengumpulkan dan menyajikan data yang diperoleh untuk menganalisis keadaan yang sebenarnya dan selanjutnya dilakukan analisa rasional berdasarkan acuan yuridis melalui penelitian kepustakaan dan penelitian lapangan. Studi Kepustakaan yaitu mencari dan menggunakan sumber dari data-data berupa Jurnal ilimiah, peraturan perundang-undangan, buku-buku, internet, artikel, dan tulisan lain yang ada hubungannya dengan materi penulisan hukum. Studi Lapangan yaitu melakukan observasi ke intansi yang menjadi objek penelitian yaitu Badan Perizinan Terpadu, serta melakukan wawancara dengan pengusaha, pengurus APINDO, pengelola perusahaan, akademisi dan praktisi hukum. Setelah data terhimpun, maka dilakukan pengolahan dan analis data secara kualitatif sehingga menghasilkan penelitian yang sesuai harapan yaitu menggambarkan keadaan sebelum dan sesudah adanya reformasi birokrasi.

Reformasibirokrasimerupakan tuntutan mas-yarakat yang harus dipenuhi untuk memperbaiki pelayanan Negara terhadap warganya. Kata reformasi berasal dari istilah latin yaitu formare yang artinya membentuk berasal dari kata forma yang artinya membentuk. Sesuai dengan kata asalnya maka istilah reformasi mempunyai beberapa pengertian yaitu: (i) Suatu perubahan kearah yang lebih baik atau suatu peningkatan; (ii) koreksi dari kesalahan, penyimpangan, atau pelanggaran; (iii) suatu tindakan untuk revolusioner. Sebagai istilah yang dipergunakan berkaitan dengan pemerintah atau Negara, maka istilah reformasi dapat berarti menempatkan suatu bentuk atau kondisi yang baru dan peningkatan; untuk memperbaiki bentuk Negara, atau membawa perubahan dari yang buruk kepada yang baik sehingga kesejahteraan sebagai tujuan 
dapat tercapai (Yefni Delfitri, 2005, 27). Pendapat yang lain mengatakan bahwa reformasi berarti perubahan dengan melihat keperluan masa depan, menekankan kembali pada bentuk asal, berbuat lebih baik dengan menghentikan penyimpangan-penyimpanagan dan praktek yang salah atau memperkenalkan prosedur yang lebih baik. Suatu perombakan menyeluruh dari suatu system kehidupan dalam aspek politik, ekonomi, hukum dan sosial. Reformasi juga berarti memperbaiki, membetulkan, menyempurnakan dengan membuat sesuatu yang salah menjadi benar. Oleh karena itu, reformasi berimplikasi untuk merubah sesuatu dan menghilangkan yang tidak sempurna menjadi lebih sempurna, misalnya melalui perubahan kebijakan institusional. Dengan demikian dapat dikemukakan karena karakteristik reformasi dalam bidang tertentu, yaitu : (1) adanya keadaan yang tidak memuaskan pada masa lalu; (2) keinginan untuk memperbaiki pada masa yang akan datang; (3) adanya perubahan besar-besaran; (4) adanya orang yang melakukan; (5) adanya pemikiran atau ide-ide baru; (6) adanya sIstem dalam suatu institusi tertentu tidak baik dalam sekala kecil maupun skala besar seperti pada institusi Negara (Yefni Delfitri, 2008, 30).

Reformasi secara umum berarti perubahan terhadap suatu sistem yang telah ada pada suatu masa. Kendati demikian, kata Reformasi sendiri pertama-tama muncul dari gerakan pembaruan di kalangan Gereja Kristen di Eropa Barat pada abad ke-16, yang dipimpin oleh Martin Luther, Ulrich Zwingli dan Yohanes Calvin. Reformasi adalah proses penataan ulang, mengubah , memperbaiki, dan menyempurnakan sesuatu agar menjadi lebih baik. Berdasarkan pengertian-pengertian diatas, maka reformasi selalu menyesuaikan diri dengan kondisi dan kebutuhan masyarakat saat ini, bahkan sebiasa mungkin dapat juga memenuhi kebutuhan masyarakat dimasa depan. Oleh karena itu, reformasi merupakan gerakan yang berlangsung terus memenerus dan tidak akan berakhir. Perubahan yang dijalankan dalam rangka reformasi tetap berpijak pada nilai-nilai dasar falsafah Negara yang sudah ada, tetapi denagn cara memperbaiki atau menyempurnakan langkah-langkah yang tidak benar. Birokrasi dewasa ini masyarakat begitu peka dengan istilah tersebut. Hampir semua lapisan masyarakat mengenal sebutan birokrasi, terutama di kalangan orang berpendidikan. Yang terdeteksi dalam pandangan mereka, birokrasi adalah urusan-urusan yang menjengkelkan, berbelit-belit, berantai, aturan ketat dan banyak sekat-sekat formalitas. Padahal birokrasi itu sendiri secara epistemologis berasal dari bahasa yunani: "Bureau", yang artinya "meja tulis atau tempat bekerja para pejabat" Sesungguhnya birokrasi itu merupakan sarana bagi pemerintah yang berkuasa untuk melaksanakan pelayanan publik sesuai dengan aspirasi masyarakat. Birokrasi adalah "tipe dari suatu organisasi yang dimaksudkan untuk mencapai tugas-tugas administratif yang besar dengan cara mengkoordinasi secara sistematis (teratur) pekerjaan dari banyak orang" (Jailani, 2006, 87). Reformasi yang terjadi mempunyai makna positif yang menandai adanya keinginan bebenah dan berubah menuju sesuatu yang lebih baik. Sementara itu birokrasi dimaknai sebagai keseluhuran organisasi pemerintah yang menjalankan tugas-tugas Negara dalam berbagai unit organisasi pemerintah dan lembaga non departemen baik di pusat maupun di daerah. Dengan demikian, reformasi birokrasi dimaknai sebagai usaha yang menjadi suatu adanya keinginan untuk merubah atau membenahi suatu organisasi pemerintah yang menjalankan tugastugas Negara dalam hal ini pelayanan publik untuk menjadi sesuatu yang lebih baik (Denok Kurniasih dan Anwaruddin, 2007, 74).

Keterbukaan informasi adalah sesuai dengan amanat Undang-undang No. 25 Tahun 2009 tentang Pelayanan Publik Pasal 4 menyatakan bahwa Penyelenggaraan pelayanan publik berasaskan yaitu: kepentingan umum; kepastian hukum; kesamaan hak; keseimbangan hak dan kewajiban; keprofesionalan; partisipatif;. persamaan perlakuan/tidak diskriminatif;. keterbukaan; akuntabilitas; fasilitas dan perlakuan khusus bagi kelompok rentan; ketepatan waktu; dan kecepatan, kemudahan, dan keterjangkauan. Tata kelola Pemerintahan yang baik atau Good Governance merupakan proses penyelenggaraan birokrasi dalam pelayanan barang dan jasa publik (Publik goods and services) yang dalam pelaksanaannya harus senantiasa berpegang pada prinsip-prinsip good governance, yaitu : prinsip efektifitas (effectiveness), keadilan, (equity), partisipasi (participation), akuntabilitas (accountability) dan tranparansi (transparency). Kalau kita cermati maka dari definisi diatas, sebuah tatanan kepemerintahan yang baik senantiasa akan meliputi 3 unsur domain yaitu: Negara, swasta dan masyarakat. Sehingga good governance mengandung pengertian nilai yang menjunjung tinggi keinginan rakyat, kemandirian, aspek fungsional dan pemerintahan yang efektif dan efisien.

UNDP menetapkan karakteristik/prinsip Good Governance sebagai berikut : 1. Participation : Setiap warga negara mempunyai suara dalam pembuatan keputusan 2. Rule of law : Kerangka hukum harus adil terutama hukum HAM 3. Tranparency : Transparansi / keterbukaan dibangun atas dasar kebebasan arus informasi 4. Responsiveness : Lembaga dan proses harus mencoba untuk melayani setiap pihak yang berkepentingan (stakeholders) 5. Consensus orientation : Good governance menjadi perantara kepentingan yang berbeda untuk memperoleh pilihan yang terbaik bagi kepentingan yang lebih luas. 6. Effectiveness and effisiency : Proses dan lembaga menghasilkan sesuai dengan apa yang telah digariskan dengan sumber yang tersedia dengan baik 7. Accountability : Pembuat keputusan, sektor swasta dan masyarakat bertanggung jawab kepada publik dan lembaga stakeholders 8. Strategic vision : Para pemimpin dan publik harus mempunyai perpektif good governance dan pengembangan manusia yang luas serta jauh ke depan (Ade Suhendar, 2010, 246).

Organisasi penyelenggara pelayanan publik yang selanjutnya disebut Organisasi Penyelenggara adalah satuan kerja penyelenggara pelayanan publik yang berada 
di lingkungan institusi penyelenggara negara, korporasi, lembaga independen yang dibentuk berdasarkan undangundang untuk kegiatan pelayanan publik, dan badan hukum lain yang dibentuk semata-mata untuk kegiatan pelayanan publik. Pelaksana pelayanan publik yang selanjutnya disebut Pelaksana adalah pejabat, pegawai, petugas, dan setiap orang yang bekerja di dalam organisasi penyelenggara yang bertugas melaksanakan tindakan atau serangkaian tindakan pelayanan publik. Masyarakat adalah seluruh pihak, baik warga negara maupun penduduk sebagai orang perseorangan, kelompok, maupun badan hukum yang berkedudukan sebagai penerima manfaat pelayanan publik, baik secara langsung maupun tidak langsung. Standar pelayanan adalah tolok ukur yang dipergunakan sebagai pedoman penyelenggaraan pelayanan dan acuan penilaian kualitas pelayanan sebagai kewajiban dan janji penyelenggara kepada masyarakat dalam rangka pelayanan yang berkualitas dan dilengkapi dengan asas-asas, norma-norma sehingga pelayanan menjadi cepat, mudah, terjangkau, terukur dan transaparan agar fungsi mereka sesuai dengan yang digariskan (Jawahir Thantowi, 2004, 241).

Reformasi birokrasi pada pelayanan publik mutlak harus berjalan karena reformasi birokrasi pintu masuk menuju pemerintahan baik yang sehat dan berkeadilan. Prinsip dan Mekanisme Pelayanan. Dalam kerangka Good Governance maka prinsip pelayanan public mencakup: (1). Efektifitas dan efisensi; (2).demokrasi; (3), Transparansi; (4), taat hukum; (5). menghargai HAM; (6). Responsife; (7), representative; (8). akuntabel (Zaidan Nawawi, 2007, 258).

Izin adalah persetujuan dari penguasa berdasarkan Undang-Undang atau peraturan Pemerintah untuk dalam keadaan tertentu menyimpang dari larangan umum tersebut. Izin adalah instrumen pemerintah dalam rangka menyelenggarakan pemerintahan dalam mengatur kepentingan umum. Izin adalah seperangkat peraturan yang berisi tentang perkenaan atau izin. Wewenang lahir karena adanya UU / hukum yang tertulis. Norma ialah isi dari hukum yaitu yang terdiri dari tiga hal : Norma perintah misalnya dalam hal Pajak, Norma larangan misalnya dalam pasal KUHP, dan Norma Membolehkan misalnya dalam KUHPerdata. Kekuasaan merupakan hak Jabatan, yang berbeda dengan Kewenangan yang merupakan hak yang dijalankan karena adanya tanggung jawab. Izin dalam istilah asing (Belanda) disebut Verguming. Bentuk Izin itu harus tertulis. HO (Hinder Ordonansi) : Hinder $=$ Gangguan, Ordonansi $=$ Peraturan, $\mathrm{HO}$ yaitu sebuah izin yang diberikan oleh masyarakat sekitar untuk usaha yang ada disitu. Nomansen Sinamo memberikan pengertian Izin adalah suatu keputusan administratif negara yang memeperkenankan sesuatu perbuatan yang pada umumnya dilarang, tetapi dapat diperkenankan dan bersifat konkrit. Izin mempunyai sifat mengendalikan suatu kegiatan atau perilaku individu atau kolektivitas yang sifatnya preventif seperti dispensasi, izin dan konsesi. Dispensi adalah keputusan administrasi yang membebaskan suatu perbuatan dan kekuasaan suatu peraturan yang menolak perbutan itu. Konsesi adalah suatu perbutan yang penting bagi umum, tetapi pihak swasta dapat turut serta dengan syarat pemerintah ikut campur (Nomansen Sinamo, 2010, 77).

Syachran Basah memberikan pengertian mengenai izin adalah perbuatan hukum administrasi negara bersegi satu yang menghasilkan peraturan dalam hal kontrol berdasarkan persyaratan dan prosedur sebagaimana ditetapkan oleh ketentuan perundangundangan yang berlaku (Nomansen Sinamo, 2010, 79). Menurut Ahmad Sobana mekanisme perizinan dan izin yang ditertibkan untuk pengendalian dan pengawasan administratif bisa digunakan sebagai alat untuk mengevaluasi keadaan dan tahapan perkembangan yang ingin dicapai, disamping untuk mengendalikan arah perubahan dan mengevaluasi keadaan, potensi serta kendala yang disentuh untuk berubah (Nomansen Sinamo, 2010, 79). Pengertian izin adalah suatu persetujuan penguasa untuk dalam keadaan tertentu menyimpang dari ketentuanketentuan larangan peraturan perundang-undangan yaitu dispensasi adalah keputusan pejabat pemerintah yang bebas suatu perbuatan dari kekuasaan peraturan yang menolak perbuatan tersebut, Lisensi adalah izin untuk menyelenggarakan perusahaan, Konsesi adalah suatu izin yang berhubungan besar dimana kepentingan umum dimana sebenarnya ada tugas pemerintah tetapi pemerintah memberikan hak kepada konsesi yang bukan pejabat pemerintah.

Pengertian Izin : ( salah satu instrumen yang paling banyak digunakan dalam hukum administrasi negara ). Izin dalam arti luas: suatu persetujaun dari penguasa berdasarkan undang-undang atau peraturan dalam keadaan tertentu menyimpang dari larangan ketentuan peraturan perundang-undangan dan hal ini menyangkut tindakan demi kepentingan umum. Izin dalam arti sempit yaitu pembebasan, dispensasi, konsesi. Izin dalam arti sempit adalah izin yang pada umumnya didasarkan pada keinginan pembuat UU untuk mencapai suatu tatanan tertentu atau menghalangi keadaan-keadaan buruk, seperti pembebasan/dispensasi adalah pengecualian atas larangan sebagai aturan umum yang berhubungan erat dengan keadaan-keadaan khusus. Konsesi adalah izin yang berkaitan dengan usaha diperuntukkan untuk kepentingan umum. Menurut Prajudi Atmosudirdjo yang dikuti Philipus M. Hadjon menerangkan bahwa izin (vergunning) adalah dispensasi dari suatu larangan. Hal ini berarti bahwa dalam keadaan tertentu suatu ketentuan hukum dinyatakan tidak berlaku untuk hal tertentu yang ditetapkan dalam suatu keputusan tata usaha negara (Helmi, 2011, 136).

Sistem perizinan diharapkan mencapai tujuan tertentu diantaranya yaitu adanya suatu kepastian hukum, perlindungan kepentingan umum, pencegahan keruksakan atau pencemaran lingkungan dan pemeratan distribisi barang-barang tertentu. Macammacam sanksi dalam hukum administrasi negara hukum perizinan merupakan bagian dari hukum administrasi. Untuk itu terhadap hukum perizinan akan diterapkan pula sanksi administrasi. Macam 
sanksi dalam hukum administrasi adalah sebagai berikut (Elita Rahmi, 2004, 126) :

1. Paksaan pemerintah (Bestuurdwang);

2. Penarikan kembali keputusan;

3. Keputusan akan ditarik kembali oleh Pemerintah, apabila :

a. Yang berkepentingan tidak mematuhi pembatasan pembatasan, syarat-syarat, atau ketentuan peraturan perundang-undangan;

b. Yang berkepentingan pada waktu mengajukan permohonan menggunakan data yang tidak benar atau tidak lengkap.

4. Pengenaan denda administratif;

5. Pengenaan uang paksa.

Prins, menyebutkan beberapa betuk atau jenis keputusan pemerintah, antara lain: dispensasi, ijin, lisensi dan konsesi. Sedangkan Ultrect, membagi ketetapan itu dalam beberapa macam atau golongan, yaitu: 1). ketetapan yang positif dan ketetapan yang negatif; 2). ketetapan yang deklaratur (declaratoir) dan ketetapan yang konstitutif (constitutief); 3).ketetapan yang kilat (vluchtig) dan ketetapan yang tetap (blijvend); 4).dispensasi (dispensatie), ijin (vergunning), lisensi (lecentie) dan konsesi (concessie) (Kaharudin, 2010, 9).

\section{HASIL DAN PEMBAHASAN}

\section{Reformasi Birokrasi Perizinan di Kabupaten Bogor}

Rencana tata ruang Kabupaten Bogor telah diarahkan untuk memenuhi fungsi resapan air dan keseimbangan air, terutama untuk menghindari penurunan nilai untuk populasi 11 juta di ibukota Jakarta. Ciliwung dan Sungai Cisadane adalah dua sungai utama yang mengalir dari Kabupaten Bogor. Setiap penurunan nilai integritas air, akan menimbulkan dampak penting bagi kesinambungan lingkungan hidup Jakarta. Kegiatana ekonomi yang dilakukan di kabupaten bogor berbasiskan sektor pertanian sehinggga tidak bertabrakan dengan tata ruang kabupaten bogor. Kabupaten Bogor adalah sebuah kabupaten di Provinsi Jawa Barat, Indonesia. Ibukotanya adalah Cibinong. Kabupaten ini berbatasan dengan Kabupaten Tangerang (Banten), Kota Depok, Kabupaten Bogor, dan Kabupaten Bekasi di utara; Kabupaten Karawang di timur, Kabupaten Cianjur dan Kabupaten Sukabumi di selatan, serta Kabupaten Lebak (Banten) di barat. Kabupaten Bogor secara garis besar terdiri atas tiga wilayah dan 40 kecamatan. Kecamatan-kecamatan tersebut dibagi atas sejumlah desa dan kelurahan. Pusat pemerintahan Kabupaten Bogor terletak di Kecamatan Cibinong, yang berada di sebelah utara Kota Bogor mempunyai luas 2.371,21 $\mathrm{km}^{2}$. Hasil Sensus Penduduk 2010 Kabupaten Bogor Berpenduduk 4.763.209 Jiwa.

Birokrasi perizinan penanaman modal merupakan tulang punggung dalam pelayanan publik, pelayanan yang publik yang baik harus efektif, efesien dan murah. Sebelum reformasi birokrasi terjadi ada hambatan-hambatan seperti : Perizinan penanaman modal di daerah sebelum adanya reformasi birokrasi tersebar dalam beberapa dinas dan badan di daerah anatara lain : Surat Izin Usaha Perdagangan (SIUP), Tanda Daftar Perusahaan (TDP), Surat Izin Usaha Industri (SIUI), Tanda Daftar Gudang (TDG) instansi yang mengeluarkan adalah Dinas Perindustrian dan Perdagangan Kabupaten Bogor, Surat Izin Usaha Jasa Konstruksi (SIUJK) instansi yang mengeluarkan adalah Dinas Bina Marga di Kabupaten Bogor, Izin Mendirikan Bangunan (IMB) instansi yang mengeluarkan adalah Dinas Tata Ruang dan Bangunan Kabupaten Bogor, Izin Pelayanan Kesehatan seperti Izin Apotek, Izin Toko Obat, Izin Praktek Dokter, Izin Praktek Bidan dan Izin Sarana Pelayanan Kesehatan instansi yang mengeluarkan adalah Dinas Kesehatan Kabupaten Bogor, Izin Analisis Dampak Lingkungan (AMDAL) instansi yang mengeluarkan adalah Badan Lingkungan Hidup Daerah Kabupaten Bogor, Izin Pertambangan Galian C dan Izin Penggambilan Air Bawah Tanah instansi yang mengeluarkan izin adalah Dinas Sumber Daya Alam dan Pertambangan Kabupaten Bogor, Izin Trayek dan Pengusaha Angkutan instansi yang mengeluarkan izin adalah Dinas Perhubungan Kabupaten Bogor, Surat Izin Usaha Pariwisata (SIUP) instansi yang mengeluarkan adalah Dinas Kebudayaan dan Pariwisata Kabupaten Bogor.

Birokasi perizinan merupakan salah satu permasalahan yang menjadi kendala bagi perkembangan usaha di Indonesia. Kondisi pelayanan perizinan saat ini masih dihadapkan pada sistem yang belum efektif dan efisien serta belum sesuai dengan tuntutan masyarakat. Hal ini dapat dilihat dari banyaknya pengaduan dan keluhan dari masyarakat baik secara langsung maupun tidak langsung mengenai kinerja aparatur dan banyaknya peraturan yang tumpang tindih, prosedur yang berbelit-belit, tidak ada kepastian jangka waktu penyelesaian, tingginya biaya yang harus dikeluarkan, banyaknya persyaratan yang harus dipenuhi, sikap petugas yang kurang responsive, sarana yang kurang menunjang dan lain-lain, sehingga menimbulkan citra yang kurang baik terhadap kinerja Pemerintah Daerah. Untuk mengatasi kondisi tersebut perlu dilakukan upaya perbaikan kualitas berkesinambungan demi mewujudkan pelayanan publik yang prima.

Upaya perbaikan kualitas pelayanan perizinan dilakukan melalui serangkaian regulasi kebijakan sebagai wujud reformasi birokrasi pelayanan publik yang telah dicanangkan oleh Pemerintah Kabupaten Bogor. Badan Pelayanan Terpadu (BPT) Kabupaten Bogor yang merupakan badan pelayanan investasi sesuai dengan amanat Peraturan Perundang-undangan yaitu adalah dibentuk berdasarkan peraturan Perundang - undangan yaitu : Undang-Undang Nomor 25 Tahun 2007 tentang Penanaman Modal, Peraturan Pemerintah Nomor 38 Tahun 2007 Antara Pemerintah, Pemerintahan Daerah Provinsi, dan Pemerintahan Daerah Kabupaten/Kota, Peraturan Pemerintahan Nomor 41 Tahun 2007 tentang Organisasi Perangkat Daerah, Instruksi Presiden Nomor 3 Tahun 2006 tentang Paket Kebijakan Perbaikan Iklim Investasi, Peraturan Menteri Dalam Negeri Nomor 24 Tahun 
2006 tentang Pedoman Penyelenggaraan Pelayanan Satu Pintu, dan Peraturan Daerah Kabupaten Bogor Nomor 23 Tahun 2008 tentang Pembentukan Badan Perizinan Terpadu Kabupaten Bogor. Pembentukan Badan Perizinan Terpadu ( BPPT ) Kabupaten Bogor berdasarkan Peraturan Daerah No. 23 Tahun 2008 pada dasarnya ditujukan untuk menyederhanakan birokrasi perizinan dalam bentuk ; Pemangkasan tahapan dan prosedur, baik prosedur lintas instansi maupun di dalam instansi yang bersangkutan; Pemangkasan biaya; Pengurangan jumlah persyaratan; Pengurangan jumlah paraf dan tanda tangan yang diperlukan; Pengurangan waktu rata-rata pemrosesan perizinan.

Badan Perizinan Terpadu Kabupaten Bogor mempunyai struktur organisasi untuk mempermudah dalam pelayanan terhadap masyarakat yaitu terdiri Birokasi perizinan merupakan salah satu permasalahan yang menjadi kendala bagi perkembangan usaha di Indonesia. Kondisi pelayanan perizinan saat ini masih dihadapkan pada sistem yang belum efektif dan efisien serta belum sesuai dengan tuntutan masyarakat. Jenis Perizinan Yang Dilayani di Badan Perizinan Terpadu Kabupaten Bogor Yaitu 40 Perizinan. Salah satu ciri Negara maju adalah diterapkannya konsep dan prinsipprinsip tata kelola pemerintahan yang baik dalam pelayanan publik, baik yang bersifat profit misalnya PDAM, listrik, telepon, transportasi, maupun yang non profit semacam STNK, SIM, KTP dan Paspor. Jenis pelayanan publik ini seharusnya memperhatikan prinsip-prinsip dasar pelayanan publik yang baik yaitu adanya keterbukaan dalam hal informasi, kepastian waktu dan harga, serta kerterjangkauannya. Selain itu juga harus diperhatikan faktor keadilan yaitu tidak diskriminatif. Kondisi pelayanan publik akan buruk apabila tidak adanya kesadaran masyarakat sendiri dan tidak adanya akses masyarakat untuk menyampaikan permasalahan- permaslahan yang ada. Pelayanan dalam artian luas adalah kegiatan yang dapat membuat pihak yang dilayani menjadi lebih mudah dan lebih nyaman dalam mendapatkan sesuatu yang boleh dalam arti kenyataannya pelayanan pemerintahan belum kooperatif dengan masyarakat (Elita Rahmi, 2004, 127). Sebelum adanya reformasi birokrasi perizinan dilakukan oleh beberapa dinas teknis di daerah seperti dinas perindustrian dan perdagangan mengeluarkan perizinan yang berkaitan dengan perizinan perdagaangan dan perindustrian yaitu surat izin usaha perdagangan (SIUP), surat izin usaha industri (SIUI), tanda Daftar Perusahaan (TDP), Tanda Daftar Gudang (TDG). Dinas bina marga yang megeluarkan perizinan yang berkaitan dengan masalah pembangunan proyek rumah, jalan dan jembatan yaitu Surat Izin Usaha Jasa Konstruksi (SIUJK). Izin Mendirikan Bangunan (IMB) instansi yang mengeluarkan adalah Dinas Tata Ruang dan Bangunan Kabupaten atau Kota. Surat Izin Usaha Pariwisata (SIUP) instansi yang mengeluarkan adalah Dinas Kebudayaan dan Pariwisata Kabupaten atau Kota.

Peraturan Menteri dalam Negeri Nomor 20 Tahun 2008 tentang Pedoman Organisasi dan Tata Kerja Unit Pelayanan Terpadu sebagai landasan maka dibentuklah badan tersendiri yaitu badan pelayanan perizinan terpadu yang mengeluarkan berbagai perizinan yang tadinya dikeluarkan oleh dinas-dinas secara terpisah maka dengan adanya badan sendiri yang bertugas mengeluarkan masalah perizinan. Dengan adanya badan pelayanan perizinan terpadu maka para pemohon perizinan cukup datang ke satu tempat maka semua perizinan dapat dimohonkan sehingga menghemat waktu dan kepastian biaya. Reformasi birokrasi mempunyai manfaat dalam proses pelayanan yang berorientasi pada kepuasan publik dan ketaatan aparatur birokasi terhadap peraturan perundang-undangan sehingga tidak terjadi penyimpangan dan perbuatan tercela. Hal ini sesuai dengan hasil dalam membangun reformasi birokasi yaitu (1). Birokasi yang bersih yang bekerja berdasarkan peraturan perundangundangan yang berlaku dan nilai-nilai yang dapat mencegah berbagai tindakan penyimpangan dan perbutan tercela,(2) Birokrasi yang efisien, efektif dan oerintasi pelanggan yaitu birokrasi yang dapat memberikan manfaat pada masyarakat dan menjalankan tugas dengan cermat dan berdaya guna, (3). Birokrasi yang transparan yang membuka diri terhadap hak masyarakat untuk mendapatkan informasi tanpa diskriminasi.

Berdasarkan Peraturan Menteri dalam Negeri Nomor 20 Tahun 2008 tentang Pedoman Organisasi dan Tata Kerja Unit Pelayanan Terpadu maka dibentuklah badan tersendiri yaitu badan pelayanan perizinan terpadu yang mengeluarkan berbagai perizinan yang tadinya dikeluarkan oleh dinas-dinas secara terpisah maka dengan adanya badan sendiri yang bertugas mengeluarkan masalah perizinan. Dengan adanya badan pelayanan perizinan terpadu maka para pemohon perizinan cukup datang ke satu tempat maka semua perizinan dapat dimohonkan sehingga menghemat waktu dan kepastian biaya. Reformasi birokrasi mempunyai manfaat dalam proses pelayanan yang berorientasi pada kepuasan publik dan ketaatan aparatur birokasi terhadap peraturan perundang-undangan sehingga tidak terjadi penyimpangan dan perbuatan tercela. Menurut pemikiran Weber suatu birokrasi modern mempunyai ciri-ciri sebagai berikut: (a) kegiatan birokrasi dilaksanakan secara teratur dengan batas-batas otoritas yang jelas, (b) ada hirarki kewenangan, (c) ada aturan yang jelas tentang perilaku, otoritas dan tanggung-jawab pegawai, dan (d) pegawai diterima atas dasar merit bukan ikatan kekerabatan.

Reformasi Birokrasi mempunyai beberapa hambatan pertama adalah karena kurang tumbuhnya budaya pelayan publik dalam birokrasi kita baik di pusat mau pun di daerah. Kelangkaan budaya pelayanan publik ini muncul sebagai akibat adanya dualisme birokrasi dalam sistem administrasi kita. Kalau sistem ekonomi kita mengenal adanya dualisme antara ekonomi tradisional-agraris dan ekonomi modern industrial, maka dalam sistem administrasi kita dikenal adanya dualisme antara sistem administrasi tradisional yang menghasilkan ritualisme administratif 
yang tidak efisien dan sistem administrasi modern yang menekankan rasionalisme administratif yang efisien. Untuk merubah inkonsistensi tata nilai yang banyak di pengaruhi ritualisme adminstratif sangat diperlukan program pendidikan dan pelatihan yang dirancang secara tepat; Kedua adalah karena kelemahan yang terkandung dalam sistem politik kita yang kurang mampu mengem-bangkan pengawasan oleh DPR dan DPRD. Salah satu sebab utama kekurang berhasilan pembangunan di negara sosialis dan Dunia Ketiga menurut kajian yang diadakan oleh Institute of Development Studies, Universitas Sussex adalah karena lemahnya sistem pengawasan demokratis di negara-negara ini. Sampai saat ini DPR dan DPRD, dengan berbagai cara, masih diperlakukan sebagai kepanjangan dari lembaga eksekutif. Karena itu tidak ada kekuatan politik yang berarti yang mengontrol lembaga eksekutif.

\section{Reformasi Birokrasi dan Keterbukaan Informasi Bidang Perizinan}

Berdasarkan tujuan dari reformasi birokrasi adalah untuk membangun pemerintahan yang bersih, meningkatkan pelayanan publik, dan tergambarkan dalam penyelenggaraan negara yang baik. Berdasarkan Presiden Nomor 03 Tahun 2006 tentang Paket Kebijakan Perbaikan Iklim Investasi. Dan ditindak lanjuti oleh Peraturan Menteri Dalam Negeri Nomor 24 Tahun 2006 tentang Pedoman Penyelenggaraan Pelayanan Satu Pintu dan Peraturan Gubernur Jawa Barat Nomor. 29 tahun tentang Perubahan Peraturan Penyelenggaraan Pelayanan Terpadu Satu Pintu maka daerah membentuk badan perizinan yang bersifat terpadu dan terpublikasi baik melalui papan pengumuman, brosur-brosur, pusat informasi dan website lembaga mengenai prosedur, persyaratan, waktu dan biaya yang di butuhkan dalam proses perizinan sehingga lembaga yang berfungsi untuk melayani proses perizinan khususnya berkaitan dengan perizinan penanaman modal.

Untuk meningkatkan pelayanan pubik kepada masyarakat yang baik sesuai dengan asas-asas umum dan prinsip-prinsip tata kelola pemerintahan yang baik khususanya asas keterbukaan yaitu yang melayani masyarakat untuk memperoleh informasi yang benar, jujur, dan tidak diskriminatif dalam penyelenggaraan administrasi pemerintahan dengan tetap memperhatikan perlindungan atas hak pribadi, golongan, dan rahasia Negara dan prinsip tranparansi yaitu dibangun berdasarkan arus informasi yang bebas. Seluruh proses pemerintahan, lembaga-lembaga dan informasi perlu dapat diakses oleh pihak-pihak yang berkepentingan, dan informasi yang tersedia harus memadai agar dapat dimengerti dan dipantau maka pemerintahan daerah membentuk masing-masing badan yang melayani perizinan yang bersifat terpadu yaitu Pemerintahan Kabupaten Bogor.

Berdasarkan Peraturan Daerah Kabupaten Bogor Nomor. 23 Tahun 2008 tentang Penbentukan Badan Perizinan Terpadu Kabupaten Bogor. Badan Perizinan Terpadu Kabupaten Bogor saat ini melayani 40 jenis perizinan. Keterbukaan Informasi merupakan salah satu asas pemerintahan yang baik terdapat dalam Pasal 3 ayat 3 Undang-Undang Nomor 28 tahun 1999 tentang Penyelenggaraan Yang Bersih dan Bebas dari Korupsi, Kolusi dan Nepotisme. Keterbukaan atau transparansi berasal dari kata dasar terbuka dan transparan, yang secara harfiah berarti jernih, tembus cahaya, nyata, jelas, mudah dipahami, tidak keliru, tidak sangsi atau tidak ada keraguan. Dengan demikian Keterbukaan atau transparansi adalah tindakan yang memungkinkan suatu persoalan menjadi jelas mudah dipahami dan tidak disangsikan lagi kebenarannya. Kaitannya dengan penyelenggaraan pemerintahan, keterbukaan atau transparansi berarti kesediaan pemerintah untuk senantiasa memberikan informasi faktual mengenai berbagai hal yang berkenaan dengan proses penyelenggaraan pemerintahan.

Makna keterbukaan dalam kehidupan berbangsa dan bernegara, dalam teori demokrasi pemerintahan yang terbuka adalah suatu hal yang esensial atau penting terutama akses bebas setiap warga negara terhadap berbagai sumber informasi, supaya tidak terjadi saling curiga antar individu, masyarakat dengan pemerintah. Keterbukaan dalam penyelenggaraan yaitu setiap kebijakan haruslah jelas, tidak dilakukan secara sembunyi, rahasia tetapi perencanaan, pelaksanaan, pertanggungjawabannya bisa diketahui publik dan rakayat berhak atas informasi faktual mengenai berbagai hal yang menyangkut pembuatan dan penerapan kebijakan. Ada 3 (tiga) alasan pentingnya keterbukaan dalam penyelenggaraan pemerintahan di sektor pelayanan publik: 1).Kekuasaan pada dasarnya cenderung diselewengkan, semakin besar kekuasaan semakin besar pula kemungkinan terjadi penyelewengan; 2). Dasar penyelenggaraan pemerintahan itu dari rakyat oleh rakyat dan untuk rakyat, agar penyelenggaraan pememrintahan itu tetap dijalur yang benar untuk kesejahteraan rakyat; 3). keterbukaan memungkinkan adanya akses bebas bebas warganegara terhadap informasi yang pada gilirannya akan memiliki pemahaman yang jernih sehingga mampu berpartisipasi aktif dalam menciptakan pemerintahan yang konstruktif dan rasional.

Prinsip mengenai pemerintahan yang terbuka tidak berarti bahwa semua informasi mengenai penyelenggaraan boleh diakses oleh publik. Ada informasi tertentu yang tidak boleh diketahui oleh umum berdasarkan undang-undang. Ciri-ciri keterbukaan menurut David Beetham dan Kevin Boyle yaitu; (1) Pemerintah menyediakan berbagai informasi faktual mengenai kebijakan yang akan dan sudah dibuatnya; (2) Adanya peluangn bagi publik dan pers untuk mendapatkan atau mengakses berbagai dkumen pemerintah melalui parlemen; (3) Terbukanya rapatrapat pemerintah bagi publik dan pers, termasuk rapat-rapat parlemen; (4) Adanya konsultasi publik yang dilakukan secara sistematik oleh pemerintah mengenai baerbagai kepemtingan yang berkaitan dengan perumusan dan pelaksanaan kebijakan. Menurut David Beetham dan Kevin Boyle ada 5 (lima) hal informasi yang tidak boleh diketahui publik yaitu: (1) Pertimbangan-pertimbangan kabinet; (2) Nasehat politis 
yang diberikan kepada menteri; (3) Informasi-informasi yang menyangkut pertahanan nasional, kelangsungan hidup demokrasi dan keselamatan individu, warga masyarakat; (4) Rahasia perdagangan dari perusahaan swasta (Suwari Akhmaddhian, 2012, 227).

Standar pelayanan pubik setiap unit pelayanan instansi pemerintahan wajib menyusun standar pelayanan masing-masing sesuai tugas dan wewe-nangnya dan dipublikasikan kepada masyarakat sebagai jaminan adanya kepastian bagi penerimaan pelayanan. Standar pelayanan merupakan ukuran kualitas kinerja yang dibakukan dalam penyelenggaraan pelayanan publik yang wajibdi ditaati oleh pemberi dan atau penerima pelayanan. Standar pelayanan yang ditetepkan hendaknya realistis karena merupakan jaminan bahwa janji atau komitmen yang dibuat dapat dipenuhi, jelas dan mudah dimengerti oleh para pemberi dan penerima pelayanan. Informasi palayanan, untuk memenuhi kebutuhan informasi pelayanan kepada masyarakat, setiap unit pelayanan instansi pemerintah wajib mempublikasikan mengenai prosedur, persyaratan, biaya, waktu, standar, akta/janji, sebagaimana telah diuraikan di atas. Publikasi dan atau sosialisasi tersebut di atas melalui antara lain, media cetak (brosur, leaflet, booklet) media elektronik (Website, Home Page, Situs Internet, radio, TV), media gambar, dan/ atau penyuluhan secara langsung kepada masyarakat (Teni Listiani, 2007, 312). Menurut pendapat Dadang Solihin dalam penerapan prinsip-prinsip tata kelola pemerintahan yang baik dalam pembangunan daerah di perlukan suatu pendekatan mempunyai parameter atau ukuran yang tergambar dalam indikator minimal dan perangkat pendukung indikator. Parameter atau ukuran berjalannya proses asas keterbukaan dan transparansi adalah (Suwari Akhmaddhian, 2012, 228) :

1. Indikator Minimal yaitu :

a. Tersedianya informasi yang memadai pada setiap proses penyusunan dan implementasi kebijakan publik;

b. Adanya akses pada informasi yang siap, mudah dijangkau, bebas diperoleh, dan tepat waktu.

2. Perangkat Pendukung indikator yaitu :

a. Peraturan yang menjamin hak untuk mendapatkan informasi;

b. Pusat/balai informasi;

c. Website ( e-government, e-procurement, dsb);

d. Iklan layanan masyarakat;

e. Media cetak dan elektronik;

f. Papan pengumuman;

g. Pameran pembangunan.

Wibawa memberikan penegertian dan pendapatnya yaitu pelayanan publik sektor ekonomi memiliki berbagai aspek. Pertama, mengenai prinsip-prinsip pelayanan ekonomi yang menerapkan kesederhanaan, kejelasan, kepastian dan ketepatan waktu, tidak diskriminatif, bertanggung jawab, kemudahan akses, kejujuran, kecermatan, kedisiplinan, kesopanankeramahan, keamanan, dan kenyamanan. Kedua, penyelenggara pelayanan ekonomi, dalam hal ini pemerintah (pusat maupun daerah), perlu menyusun dan menetapkan standar, antara lain meliputi persyaratan, prosedur pelayanan, waktu penyelesaian, biaya pelayanan, kompetensi petugas, pengawasan intern, penanganan pengaduan, saran/ masukan, dan jaminan pelayanan. Penyelenggaraan pelayanan ekonomi juga harus menyelenggarakan penilaian kinerjanya melalui survei indeks kepuasan masyarakat secara periodik. Ketiga, pentingnya ruangruang publik sebagai akses masyarakat jtka pelayanan ekonomi tidak memuaskan. Jika penyelenggara pelayanan ekonomi tidak memuaskan, masyarakat dapat mengajukan klaim, malah menggugat ke meja hijau (T. Nazarudin Sulaiman, 2008, 5).

Berdasarkan penjelasan diatas mengenai pengertian dan indikator-indikator tentang asas-asas umum dan tata kelola pemerintahan yang baik khususnya asas keterbukaan dan transparansi maka Badan Perizinan Terpadu Kabupaten Bogor sudah melakukan keterbukaan informasi karena selama ini sudah memberikan informasi yang jelas melalui media papan pengumuman, brosur, pusat informasi dan khususnya website instansi Badan Perizinan Terpadu Kabupaten Bogor (www.bpt.bogorkab. go.id) sehingga masyarakat mendapatkan informasi yang jelas berkaitan dengan proses perizinan seperti formulir, prosedur, persyaratan, waktu serta biaya perizinan.

\section{SIMPULAN}

Reformasi Birokrasi Perizinan di Kabupaten Bogor dimulai berdasarkan Peraturan Presiden Nomor 03 Tahun 2006 tentang Paket Kebijakan Perbaikan Iklim Investasi, dan ditindak lanjuti oleh Peraturan Menteri Dalam Negeri Nomor 24 Tahun 2006 tentang Pedoman Penyelenggaraan Pelayanan Satu Pintu dan Peraturan Gubernur Jawa Barat Nomor. 29 Tahun 2008 tentang Perubahan Peraturan Penyelenggaraan Pelayanan Terpadu Satu Pintu maka Kabupaten Bogor berdasarkan Peraturan Daerah Kabupaten Bogor Nomor. 23 Tahun 2008 tentang Penbentukan Badan Perizinan Terpadu Kabupaten Bogor. Badan Pelayanan Perizinan Terpadu Kabupaten Bogor saat ini melayani 40 jenis perizinan, 14 jenis perizinan diantaranya sudah mendapatkan Sertifikat SMM ISO 9001:2008 untuk 14 Pelayanan Perizinan dari PT. Sucofindo.

Pengaruh Reformasi Birokrasi Perizinan di Kabupaten Bogor terhadap Keterbukaan Informasi yang nyata yaitu dapat diukur dengan indikator tersedianya informasi yang memadai yang berkaitan dengan prosedur, syarat-syarat dan hal-hal yang berkaitan dengan proses perizinan di Badan Perizinan Terpadu Kabupaten Bogor mudah di akses dengan dipublikasikan melalui media brosur, papan pengumuman, pusat informasi dan terutama adalah website instansi (www.bpt.bogorkab.go.id), berbeda dengan sebelum reformasi birokrasi informasi susah di dapatkan oleh masyarakat luas.

Kepada Pemerintahan Daerah Kabupaten Bogor dan Badan Perizinan Terpadu Kabupaten Bogor harus meningkatkan sarana pra-sarana yang mendukung kegiatan operasional sehingga meningkatkan proses 
pelayanan menjadi lebih cepat serta memperluas lahan parkir untuk mempermudah masyarakat dalam menyimpan kendaraannya sehingga ketika pemohon perizinan dalam melakukan proses permohonan perizinan menjadi lebih nyaman dan aman dan menambah gudang arsip supaya daya tampung dokumen meningkat sehingga arsip-arsip dokumen rapi dan aman.

Kepada Badan Perizinan Terpadu Kabupaten Bogor harus melakukan dan meningkatkan publikasi atau sosialisasi yang menarik di tempat-tempat strategis atau daerah yang potensial masyarakat memerlukan informasi mengenai perizinan serta memperkuat jaringan dan memperbesar kapasitas website Instansi Badan Perizinan Terpadu Kabupaten Bogor.

\section{DAFTAR PUSTAKA}

Ade Suhendar. 2010. Keterbukaan Informasi Publik Bentuk Keseriusan Pemerintah Menuju Good Governance (Implementasi Undang Undang Nomor 14 Tahun 2008). Jurnal Wacana Kerja. Volume 13 No.2: 243-251.

Asmara Budi Dyah Dharma Sutji. 2008. Ombudsman di Indonesia. Jurnal Hukum dan Masyarakat. Volume 33 No.1:67-78.

Asri M Saleh. 2004. Arti Penting Kehadiran Ombudsman Bagi Masyarakat Di Provinsi Riau. Jurnal Hukum Respublica. Volume 33 No.1:228-237.

Denok Kurniasih dan Anwaruddin. 2008. Reformasi Birokrasi Pelayanan Perizinan di Kabupaten Banyumas (Studi di Kantor Pelayanan Perizinan dan Investasi). Jurnal Humanis. Vol. I No. 2:72-79.

Elita Rahmi. 2004. Perizinan Dalam Pemerintahan (Sebuah Tantangan dan Harapan di Era Otonomi). Jurnal Hukum Respublica. Vol. 4 No.1:122-130.

Helmi. 2011. Membangun Sistem Perizinan Terpadu Bidang Lingkugan Hidup di Indonesia. Jurnal Dinamika Hukum. Vol. 11 No.1:134-142

Jailani. 2006. Urgensi Nilai-Nilai Akhlaq Pada Birokrasi Pemerintahan dalam Pelayanan Publik. Jurnal Al-Bayan. Vol. 12 No. 13:81-96.

Jawahir Thontowi. 2004. Norma Hukum Pelayanan Publik. Jurnal Hukum. Vol. 14 No.3:435-449.
Kaharudin. 2010. Perluasan Kompetensi Absolut Peradilan Tata Usaha Negara Pasca berlakunya Undang-Undang No.14 Tahun 2008 Tentang Keterbukaan Informasi Publik. Jurnal Yustisia. Edisi 81:5-21.

Nomensen Sinamo, 2010, Hukum Administrasi Negara, Jakarta : PT.Jala Permata Aksara.

Peraturan Daerah Kabupaten Bogor Nomor. 23 Tahun 2008 tentang Penbentukan Badan Perizinan Terpadu Kabupaten Bogor.

Peraturan Gubernur Jawa Barat Nomor. 29 Tahun 2008 tentang Perubahan Peraturan Penyelenggaraan Pelayanan Terpadu Satu Pintu.

Peraturan Menteri Dalam Negeri Nomor 24 Tahun 2006 tentang Pedoman Penyelenggaraan Pelayanan Satu Pintu.

Peraturan Presiden Nomor 03 Tahun 2006 tentang Paket Kebijakan Perbaikan Iklim Investasi.

Riyadi Soeprapto. 2005. Pengembangan Model Citizen Charter Dalam Meningkatkan Pelayanan Publik Di Indonesia. Jurnal Delegasi. No. 2 Agustus 2005:123-150

Suwari Akhmaddhian. 2012. Pengaruh Reformasi Birokrasi Terhadap Perizinan Penanaman Modal di Daerah (Studi Kasus di Pemerintahan Kota Bekasi), Jurnal Dinamika Hukum. Vol.3 No.3:222-234.

T.Nazarudin Sulaiman. 2008. LandasanTeoritik Pelayanan Perizinan Terpadu Satu Pintu. Suloh:Jurnal Penelitian dan Pengkajian Hukum. Volume 6 No. Ed. Khusus 2008:1-26

Teni Listiani. 2007. Volume IV No. 3 September 2007, Implemntasi Kebijakan Transparansi dan Akuntabilitas Pelayanan Publik (Studi di PDAM Kota Bandung). Jurnal Ilmu Administrasi. Volume IV No. 3:303-318.

Undang- Undang Nomor 25 Tahun 2009 tentang Pelayanan Publik.

Yefni Delfitri, 2005, Reformasi Birokrasi di Mahkamah Agung, Jakarta: Universitas Krisnadwipayana.

Zaidan Nawawi. 2007. Kinerja Pelayanan Publik, Jurnal Eksekutif. Volume 4 No. 2:257-262. 